\title{
Transfer of criminal proceedings: from stumbling block to cornerstone of cooperation in criminal matters in the EU
}

\author{
Boudewijn de Jonge ${ }^{1}$ \\ Published online: 10 July 2020 \\ (C) The Author(s) 2020

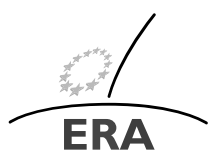 \\ EUROPÄISCHE RECHTSAKADEMIE \\ ACADEMY OF EUROPEAN LAW \\ ACADEMIE DE DROIT EUROPEEN \\ ACCADEMIA DI DIRITTO EUROPEO \\ TRIER - TREVES - TREVIRI
}

\begin{abstract}
Most forms of international cooperation in criminal matters have now been regulated to some extent by European Union legislation. One classical form of cooperation has been so far largely immune from influence by the EU legislator, however. This is the area of transfer of proceedings. This article provides an overview of the current situation and argues that new life should be blown into earlier initiatives to improve this form of cooperation. Harmonisation in this area will prove an important step to facilitate the proper administration of justice in the common Area of Freedom, Justice and Security that the European Union is set to realise.
\end{abstract}

Keywords Transfer of proceedings · Jurisdiction conflicts $\cdot$ International cooperation in criminal matters

\section{Introduction}

A transfer of proceedings is the process in which the competent authority of one state transfers a criminal case against a particular suspect to the competent authority of an-

The author is currently preparing a $\mathrm{PhD}$ project on judicial cooperation in transnational organized crime cases, to be carried out under the supervision of Leiden University.

Disclaimer: The views expressed in this article are those of the author and do not necessarily reflect the position of the Dutch government.

B. de Jonge

ircdenhaag@om.nl

1 LLM. Public prosecutor in the Serious Organised Crime Department of the Public Prosecution Service, The Hague, The Netherlands 
other state, with the request to consider prosecution. ${ }^{1}$ In its most common and legally least complex form, the receiving state has original jurisdiction over the alleged facts. A limited number of international instruments have gone a step further and allow the receiving state to assume jurisdiction upon acceptance of the transfer; these instruments create so-called subsidiary jurisdiction for the receiving state over the facts. The introduction of subsidiary jurisdiction allows in essence a case to be transferred to any other state.

A wide variety of reasons can be given why a transfer of a proceeding is desirable in a particular case. It might be that most evidence is located in another jurisdiction, or that both the suspect and the victim originate in another state. Generally speaking, a transfer should be done in the interests of proper administration of justice. Nonetheless, it is not always obvious how the administration of justice is best served in a specific case. The interest of society, prosecution, defence, co-defendants or victims may not be aligned at all in this respect. Given that a transfer of a case to a different jurisdiction may have both practical and legal consequences, the stakes involved can be high when a transfer is considered. Different rules of evidence and penalties will apply, for instance. Judicial oversight of decisions to transfer is at present not provided for in international instruments.

Transfer of proceedings is one of the last areas of mutual legal assistance scarcely touched upon by EU legislation. The exchange of police information, the gathering of evidence, the freezing of assets and extradition have all been radically changed by various directives and regulations. This is not so with this otherwise common form of cooperation. This may come as a surprise, when one realises that it clearly falls within the legislative competence of the European Union. One might expect wide support for an instrument which facilitated having a criminal case judged in the state best positioned to do so. In fact, no less than fifteen Member States supported in 2009 the proposal to come up with a Framework Decision in this field. Indeed, at the time, it was characterised as a future cornerstone of cooperation. ${ }^{2}$

Nevertheless, any European law that touches on the extent of the jurisdiction of national criminal judges, is likely to have far reaching implications from a legal and practical point of view and will be heavily debated. A directive that actually obliges states to accept incoming requests for transfers limits the discretion of prosecuting authorities and creates a workflow for national courts of which the size is difficult to assess beforehand. Resistance proved to exist with several Member States against an obligatory extension of their jurisdiction to offences which had taken place outside their territory. Further, Luchtman has remarked that it takes a high level of trust for a system to have its own investigations ending in a foreign trial. ${ }^{3}$ Also from a practical point of view, to take a criminal file to court which is largely compiled by foreign authorities does take a quite bit of courage. Evidence which is gathered in accordance with foreign rules and customs, and working with a translation of a foreign case file

\footnotetext{
${ }^{1}$ Sometimes the term 'transfer of prosecution' is used instead of 'transfer of proceedings'. Although I agree that the first term more accurately describes this form of cooperation, I will use only the legal term used in the relevant (draft) international instruments in this article.

${ }^{2}$ Council: Draft [... ] on Transfer of proceedings in criminal matters, 24.11.2009, 16437/09, p. 3.

${ }^{3}$ See for instance Luchtman [1], p. 8 .
} 
both pose challenges to practitioners. From a human point of view, it is understandable that a file with such 'complications' may not always receive the same priority as a similar national case.

Although there might be untapped potential in this possible cornerstone of cooperation, the way to unlock that potential appears to be scattered with practical and fundamental considerations. Let us first have a look at the current legal situation and practice, after which we turn to past and possible future developments in this field.

\section{Current legal situation}

The primary international instrument dedicated solely to transfer of proceedings is the 1972 European Convention on Transfer of Proceedings, elaborated by the Council of Europe (hereinafter: the 'Transfer Convention'). ${ }^{4}$ At the present time, only thirteen Member States of the European Union have ratified this Convention. The Convention allows for a transfer to be initiated for a number of reasons. Amongst the reasons listed in Article 8 are the origin of the suspect, the aim of concentrating parallel proceedings, rehabilitation prospects, and the main localisation of the evidence. The Convention sets out a framework of provisions on the procedure, the right of the suspect to be heard on the transfer, the right of translation and on provisional arrest. In order to avoid ne bis in idem issues, Article 3 allows the transferring state to end its criminal procedure; this is of particular relevance to states with a strict legality principle.

The Convention restricts the number of grounds for the refusal of an incoming request to a limitative list. Notwithstanding the fact that this concerns a limited list of refusal grounds, the receiving state has a wide discretion to reject a request. This is because the first refusal ground allows the receiving state to review in full the justification of the proposed transfer. Thus, a transfer can only take place with the consent of both states.

The distinctive contribution of the Convention is the introduction in Article 2 of a wide subsidiary jurisdiction that allows a Contracting State to take over a prosecution from any other Contracting State. This mechanism makes it possible to consider with an open mind the question of how the proper administration of justice is best served in a specific case; or better: in which country a trial will best serve the good administration of justice. The Convention does not introduce a clear hierarchy between possible venues, but it clearly opens the possibility of weighing the interests of all actors involved when considering the reallocation of a criminal case to another state.

In case a state has not ratified the Transfer Convention and no other bilateral treaty is in place, a transfer of proceedings can only take place in so far the requested state has original jurisdiction. A number of bilateral and multilateral treaties contain provisions on how one state may request another state to open a case, which can be seen as a de facto transfer of proceedings. Authorities may for instance rely on Article

\footnotetext{
${ }^{4}$ European Convention on Transfer of Proceedings of 15 May 1972, Strasbourg, (ETS No. 073, 1972).
} 
21 of the 1959 European Convention on Mutual Assistance in Criminal Matters. ${ }^{5}$ In that case, the procedure to be followed and effects of the transfer are largely unregulated. The Convention only regulates whether or not the requesting state should provide a translation of the information supplied to the requested state, and prescribes the requested state to communicate the outcome of the procedure to the requesting state.

Another legal basis relied upon for the transfer of a criminal file is the spontaneous exchange of evidence, for instance on the basis of Article 7 of the 2000 Convention on Mutual Assistance in Criminal Matters between the Member States of the European Union. ${ }^{6}$ In that case, the effects of the transfer are entirely unregulated. The receiving state does not even have an obligation to provide feedback to the transferring state. This legal basis serves well when there is a high level of trust between the authorities involved, or prior consultation has taken place.

\section{Current practice}

Whereas transfers of proceedings are considered a potential 'cornerstone of international cooperation', it will not come as a surprise that both the European Judicial Network (EJN) and Eurojust have addressed this form of cooperation on multiple occasions. From their reports, it has become clear that the current situation is far from ideal.

Eurojust organised for instance in June 2015 a Strategic Seminar on conflicts of jurisdiction, transfer of proceedings and ne bis in idem. In the report on the outcome of that seminar, Eurojust listed numerous challenges with respect to the practice of transferring proceedings. ${ }^{7}$ This list included differing rules on evidence, the cost and quality of translations, as well as a lack of consultation, coordination and time limits for decisions to be taken. Moreover, the lack of involvement of victims and suspects in decision-making on a transfer was considered a shortcoming.

In 2018 Eurojust published a report with an update on its experiences in this field. ${ }^{8}$ The report highlighted the difficulties that continued to exist whenever states have not ratified the Transfer Convention. By and large, it reiterated the same obstacles as had been mentioned in the 2015 report. Additionally, it noted the time-consuming character of a transfer of proceeding, as well as the lack of interest in potential transfers in foreign jurisdictions. ${ }^{9}$ At the same time, the report notes that sometimes no formal transfer is needed since all evidence required is already present in the receiving state. However, even in that situation a formal decision on the national level to discontinue

\footnotetext{
${ }^{5}$ European Convention on Mutual Assistance in Criminal Matters of 20 April 1959, Strasbourg, (ETS No. 030, 1959).

${ }^{6}$ Council Act of 29 May 2000 establishing in accordance with Article 34 of the Treaty on European Union the Convention on Mutual Assistance in Criminal Matters between the Member States of the European Union, [2000] OJ C 197/1.

${ }^{7}$ Eurojust [6], p. 8.

${ }^{8}$ Eurojust [2].

${ }^{9}$ In 2016, Eurojust mentioned, in particular, cases of VAT fraud as cases that Member States would be reluctant to take over from each other. Eurojust: Eurojust News. Issue 14, 2016, p. 8.
} 
the proceeding is still needed. This may still cause a challenge when a ground for dismissal of the case in the transferring state is not easily found.

During panel discussions at the June 2019 Plenary Meeting of the European Judicial Network, the problematic lack of clear rules on the effect of transfers was widely acknowledged by the participants. Tellingly, it was noted that in the present situation it may seem easier and faster to use the well known procedure of a European Arrest Warrant, than to transfer a case. ${ }^{10}$

In my own practice as a receiving authority of transferred proceedings, I see all of these challenges reflected. Usually, the incoming transfer has been initiated on very reasonable grounds by the foreign authority. Due to the various challenges, only a small percentage of the accepted incoming cases end up before a judge. In reality, transferred cases are often experienced more as stumbling stones, due to the alien element of these cases and long delays have already been suffered when the case arrives. The lack of clear prospects regarding what will happen to their case after a transfer, also holds back colleagues from initiating a transfer to another Member State.

It seems that even in the states that have implemented the Transfer Convention, this form of cooperation is generally little known or used. A large group of experts (both academics and practitioners) from all European Union Member States was asked in 2012 if it would be desirable to draft a list of potentially acceptable criteria for establishing in which situations a transfer of proceedings is recommendable. ${ }^{11}$ An overwhelming $90 \%$ of the participants confirmed the need for such guidelines.

The costs of translation have always been mentioned as a practical obstacle to the transfer of proceedings. The translation of a file consisting of several hundreds of pages, may easily run into ten of thousands of euros. It is often not possible to profit from the price differences for translation within the European Union, because of national procedural rules that prescribe the use of a nationally accredited translator. Nevertheless, in many cases it remains to be seen if the one-time costs of a transfer of proceeding are indeed higher than the costs of translation and interpretation if the case is kept in the one country. The introduction of the 2010 Directive on right of interpretation and translation, has introduced a set of minimum rights for suspects in this respect. ${ }^{12}$ Not only has the suspect a right to interpretation throughout the investigation and trial, but he also has the right that essential documents of the court file and crucial evidence be translated.

\section{Proposal for a European Union instrument in 2009}

Already in the 1980s, the UN and the European Communities worked on initiatives to broaden the international legal basis for transfers of proceedings. The UN General Assembly adopted a Model Treaty in 1990, and in the same year the European

\footnotetext{
${ }^{10}$ Council: 52nd Plenary meeting of the European Judicial Network (EJN) - Conclusions on the role of the EJN in fostering the practical application of the EU mutual recognition instruments. 5.12.2009. 14501/19, p. 8 .

${ }^{11}$ Vermeulen, De Bondt, and Ryckman, [9], p. 476.

${ }^{12}$ Directive 2010/64/EU of the European Parliament and of the Council of 20 October 2010 on the right to interpretation and translation in criminal proceedings [2010] OJ L 280/1.
} 
Communities agreed upon the EPC Agreement on the Transfer of Proceedings in Criminal Matters. That convention did not enter into force since it received only two ratifications. Under the Swedish presidency of the Council a proposal for a Framework Decision was tabled in 2009. ${ }^{13}$ The initiative was supported by sixteen states. The ultimate aim of the proposal was described as:

$[\ldots]$ to increase efficiency in criminal proceedings and to improve the proper administration of justice in line with the EU's aim of creating a common European area of freedom, security and justice. To this end, it strives for common rules facilitating the transfer of criminal proceedings between competent authorities of EU member states with, in particular, increased transparency and greater objectivity in the way in which the place for the trial is chosen.

The proposal contained a detailed procedure for transfers. It included a right for the suspect to give his or her views on an intended transfer, prescribed prior consultation between the competent authorities, and gave the European Judicial Network and Eurojust a role should obstacles occur. Moreover, a rule of equivalence was included, which ensured that all investigative steps taken before the transfer were to be considered as having been performed in the requested state.

The Presidency of the Council wanted the text of the proposed Framework Decision to go beyond what was already possible under the instruments existing at that time. However, discussions in the Working Party on Cooperation in Criminal Matters watered down some of the features that characterised the proposal.

The issue that met with the most resistance - although only from a small number of Member States- was the obligatory extension of national jurisdiction by the Member States. The initial proposal introduced in Article 5 an obligation to establish subsidiary jurisdiction. Although this article received support from the majority of Member States, several others had fundamental objections to it. The Presidency of the Council considered this topic essential to the whole proposal. In response to the objections, the Council came up with two options. ${ }^{14}$ Under Option A, jurisdiction was to be assumed at least if (i) the offence was committed or damage was caused in the receiving state, or (ii) the accused person or (iii) victim was national or resident in the receiving state. Under Option B, two additional grounds for subsidiary jurisdiction were proposed: when (iv) there were ongoing procedures in the receiving state against the same person or (v) ongoing proceedings concerning related facts or the same organisation.

Ludwiczak concluded that the proposed Directive would indeed bring about the paradigmatic change that no longer Member States alone but rather the European Union would determine national rules on jurisdiction. ${ }^{15}$ Further, she observed that the last version of the negotiated text did actually not go as far as the Transfer Convention, since a transfer would not be possible if no extraterritorial element was present in the case. $^{16}$

\footnotetext{
${ }^{13}$ Draft Council Framework Decision on the transfer of proceedings in criminal matters, 30.06.2009, 11119/09. And: Explanatory Report, 3.7.2009, 11119/09 Add 1.

${ }^{14}$ Draft [...] on Transfer of proceedings in criminal matters, 24.11.2009, 16437/09, p. 5.

${ }^{15}$ Ludwiczak [5], p.352.

${ }^{16}$ Idem, p. 535 [corrigendum].
} 
The proposed system of transfer of proceedings was not based on the principle of mutual recognition: the transfer would be set in motion on the basis of a simple request and not by way of an order. The initial text of the proposal restricted the possibility of a receiving state refusing a request for a transfer to a limited list of situations. In the later version of the proposal, this was weakened to one broad ground for refusal: if the receiving authority disagreed with the assessment that a transfer would improve the efficient and proper administration of justice.

Though some NGOs questioned the need for European Union legislation on the matter, ${ }^{17}$ the Meijers Committee welcomed the proposal as well-balanced and a completion of the network of cooperation. ${ }^{18}$ The Working Party on Cooperation in Criminal Matters of the Council worked intensively on the text of the proposal between June and November 2009. By December of that year the question of the extension of national jurisdiction remained one of last points under discussion. Due to the adoption of Lisbon Treaty, it was decided in December 2009 that a new proposal would have to be drawn up. ${ }^{19}$ After that, attention shifted toward the establishment of the European Public Prosecutor's Office and other legislative priorities, and this project came to a standstill.

\section{Ever-increasing need for an instrument on transfer of proceedings}

\subsection{Criminal policy perspective}

Both the perspective of effectively combating transnational crime and the perspective of human rights should inspire the European Union legislator to take up again this issue. A look at the continuing internationalisation of crime makes clear that the good administration of justice is likely served by more transfers of proceedings.

In the first place, the open borders in the Schengen area and the ease in general of moving across Europe, have also enabled criminals to be more easily active across borders. The same burglar may easily visit residences in three different countries in three consecutive nights. It is not seldom for criminal organisations involved in organised property crime to have the entire European Union as their working area. These developments increase the chance that one suspect is involved in criminal proceedings in multiple jurisdictions at the same time. The concentration of several pending proceedings in one joined case, may simplify the legal process, allow for a better understanding of the role of a suspect, and lead to a more just sentence.

Another effect of open borders is that large numbers of people reside temporarily in country other than that of their nationality. When they become involved as a suspect in a criminal case, they are likely to have already moved home or to another country

\footnotetext{
${ }^{17}$ See, for instance, European Foundation: Brussels set to regulate transfer of criminal proceedings between EU Member States (2009). Available at www.europeanfoundation.org. And: JUSTICE: Draft Council Framework Decision on the transfer of proceedings in criminal matters Briefing July 2009 (2009). Available at: www.eerstekamer.nl.

${ }^{18}$ Meijers Commission [7].

${ }^{19} 2979$ th Council meeting, JHA, 30 November and 1 December 2009, 16883/1/09 REV 1.
} 
by the time the decision to prosecute is taken. In some cases, it would be in the interest of all parties to have the case then dealt with in the actual country of residence.

Secondly, increasing economic integration has also taken place on the black markets. Europol observed in a 2017 report that some 5000 international organised crime groups were under investigation within the European Union. ${ }^{20}$ The functioning and effects of each of those criminal organisations can be felt in multiple jurisdictions. Parallel investigations or prosecutions may be underway, or it may actually be desirable to split a case. In my own practice, I frequently see how foreign drugs investigations implicate suspects from my own jurisdiction. It is not uncommon that upon consultation with the foreign judicial authority a division of labour is agreed. After a transfer of proceeding, the foreign case becomes the basis for a prosecution in my own country.

Thirdly, cyberspace has been rapidly gaining ground as locus delicti. A click of a mouse can set in motion a phishing operation aimed at victims all over the world. It has become increasingly easy to target victims in another country, since the dark web offers relevant tools and data that enables a criminal to tailor its action to another language area. A foreign bank account is opened online in a matter of minutes, which gives a local appearance and generates a smoke curtain. Time and time again in cyber crime investigations, I see the same suspect or criminal organisation under investigation in several countries. It is not seldom that each of those separate investigations only looks at the victims who happen to reside in their jurisdiction.

In all of these cases, the administration of justice would be served better if cases could be joined, separated or simply sent to another jurisdiction.

\subsection{Human rights perspective}

The current lack of a harmonised European Union framework for the transfer of proceedings may affect the position of European Union citizens adversely in various ways, both suspects and victims alike.

In the first place, it may well be that an otherwise logical transfer is simply legally not possible. The suspect or victim may have to travel extensively to attend a trial abroad. And a suspect may even face a European Arrest Warrant to secure his or her attendance abroad. And if a de facto transfer takes place, a suspect may be confronted with a much higher sentence in a foreign jurisdiction. Conversely, a transfer may run counter to the legitimate expectations of a victim concerning the sentence, when a more lenient sentencing practice is followed in the receiving state.

Suspected persons and victims have at this moment little say in where a prosecution will take place, if multiple venues are possible. In particular if the informal way of transferring a proceeding is used, via the spontaneous provision of evidence, the choices of the authorities remain somewhat secretive and are often not subject to judicial review. Further defence rights that would be served by harmonisation in this area are foreseeability and ne bis in idem, which we will now look at in more detail.

${ }^{20}$ Europol: European Union (EU) Serious and Organised Crime Threat Assessment (SOCTA) 2017. 


\subsection{Positive jurisdiction conflicts and ne bis in idem}

The need for better European arrangements for transfers of proceedings is closely connected to the persistent calls to have better European rules on the prevention of positive jurisdiction conflicts and ne bis in idem.

Many states have moved away from the idea that their jurisdiction should be tightly restricted to their own territory. Based on active or passive personality principles, or judging by the effect of an act, many countries have assumed jurisdiction over acts performed outside their own territory. Parallel proceedings may therefore be initiated related to the same or strongly related facts. It is here that a positive jurisdiction conflict might arise. The ne bis in idem principle dictates that double prosecution or double execution of sentence in respect of the same facts is not possible.

In all instruments of mutual recognition, the ne bis in idem principle is included as one of the possible grounds to refuse execution of an order received. Already in the investigative phase, Member States are pushed to avoid bis in idem situations: the Directive on the European Investigative Order (EIO) includes as a refusal ground that the ne bis in idem principle would be violated. ${ }^{21}$ The European Arrest Warrant Framework Decision not only includes ne bis in idem as a ground for refusal, but also the situation in which the offence has been (partially) committed on the territory of the executing state (see Article 4(7)). Basically, this attributes a right of priority to the Member State where the suspect is found. ${ }^{22}$ A refusal on this ground is in no way accompanied by an obligation on behalf of the refusing state to actually initiate any criminal investigation by itself. The Romanian presidency of the Council suggested that an obligation aut dedere aut judicare could be introduced, to prevent a refusal ends in impunity. In this way a refusal to execute a European Arrest Warrant would be followed up by the transfer of the criminal proceeding. ${ }^{23}$

Currently, when multiple jurisdictions are competent to prosecute, no rules on priority exist. It seems to be first come, first served. Already in 2003 Eurojust published 'Which jurisdiction should prosecute?'- guidelines for deciding this - a non-binding set of factors to be taken into account whenever multiple jurisdictions have competence. ${ }^{24}$ The Lisbon Treaty now instructs the European Union in Article 81 (1) (b) to adopt measures to prevent and settle jurisdiction conflicts in criminal matters. It can well be argued that for the attainment of both objectives - i.e., the prevention and settlement of these conflicts - harmonised rules on the transfer of proceedings are indispensable. However, no binding instrument exists or has even been proposed. The 2009 Framework Decision which deals with conflicts of jurisdiction only establishes information and consultation procedures, but does not touch upon the outcome of such consultations. ${ }^{25}$

\footnotetext{
${ }^{21}$ Article 11 (1) (d) of Directive 2014/41/EU of the European Parliament and of the Council of 3 April 2014 regarding the European Investigation Order in criminal matters [2014] OJ L 130/1.

${ }^{22}$ See on this matter also: Luchtman [8], p 93.

${ }^{23}$ Council: The way forward in the field of mutual recognition in criminal matters - Policy debate. 27.5.2019. 9728/19, p. 18.

${ }^{24}$ Eurojust: Guidelines for deciding 'Which jurisdiction should prosecute?' Revised 2016. Available at: www.eurojust.europa.eu.

${ }^{25}$ Framework Decision 2009/948/JHA of 30 November 2009 on prevention and settlement of conflicts of exercise of jurisdiction in criminal proceedings.
} 
It has been frequently remarked that the prominence of the ne bis in idem principle is not yet matched with a system for easily identifying parallel proceedings. ${ }^{26}$ No common database exists of ongoing investigations or prosecutions. Whereas at the national level, a criminal record will usually easily reveal if a suspect has any pending cases, such information is not available at European Union level. ${ }^{27}$ The European Criminal Records Information System (ECRIS) reveals only cases that have been irrevocably decided. The earlier a potential jurisdiction conflict is identified, the earlier it may be solved, for instance by a transfer of proceedings from one jurisdiction to the other.

In order to promote an early identification of parallel police investigations and judicial procedures, the European Union has adopted various instruments. In 2009, the Eurojust Decision was supplemented by creation of an obligation on the part of the Member States to inform Eurojust of cases in which jurisdiction conflicts arose. ${ }^{28}$ Moreover, a limited, yet complex obligation was introduced to inform Eurojust of cases involving three or more Member States. ${ }^{29}$

Various scholars have proposed over the years that positive jurisdiction conflicts should be resolved by a set of binding, objective criteria on a European level. ${ }^{30}$ In a 2005 Green Paper, the Commission also put forward the suggestion of a binding mechanism for case allocation, with the ultimate aim of avoiding double proceedings and concentrating parallel criminal proceedings in one leading Member State. ${ }^{31}$ Any binding mechanism for case allocation will naturally determine that certain cases have to be transferred to another jurisdiction.

As there are no European Union rules on where a cross-border offence should be prosecuted, this leads to legal uncertainty. Within each national legal system the rules on jurisdiction are strictly applied, as each criminal case should be tried by the competent court established by law. But when it comes to the question where a particular cross-border case should be tried, no clearly defined rules exist. Luchtman, for one, has argued extensively, that this situation is contrary to the right to be heard

See on the various possible outcomes after consultation: Report from the Commission to the European Parliament and The Council on the implementation by the Member States of Framework Decision 2009/948/JHA [...]. 2.6.2014. COM(2014) 313 final, p. 10.

Further obligations to coordinate parallel proceedings are included in: Directive (EU) 2017/541 of the European Parliament and of the Council of 15 March 2017 on combating terrorism and replacing Council Framework Decision 2002/475/JHA and amending Council Decision 2005/671/JHA, [2017] OJ L 88/6, Article 19. Also Directive 2013/40/EU of the European Parliament and of the Council of 12 August 2013 on attacks against information systems and replacing Council Framework Decision 2005/222/JHA, [2013] OJ L 218/8, Article 12.

${ }^{26}$ For instance, Schomburg [4], p 320.

${ }^{27}$ The automated sharing of certain investigation data with the Europol Information System (EIS) and the automatic matching of that data, is a promising development. The EIS can assist Member States in identifying parallel investigations in an early stage.

${ }^{28}$ Council Decision 2009/426/JHA of 16 December 2008 on the strengthening of Eurojust and amending Decision 2002/187/JHA setting up Eurojust with a view to reinforcing the fight against serious crime, [2009] OJ L 138/14. Article 13 (7), in the Eurojust Regulation transposed to Article 21 (6).

${ }^{29}$ Idem, Article 13 (6), in the Eurojust Regulation transposed to Article 21 (5).

${ }^{30}$ See for instance Luchtman, [1], p. 55.

${ }^{31}$ Green Paper on Conflicts of Jurisdiction and the Principle of ne bis in idem in Criminal Proceedings $\operatorname{COM}(2005) 696$. 
by a tribunal previously established by law, as enshrined in Article 47 of European Union Charter of Fundamental Rights. ${ }^{32}$ The absence of any binding rules or even guidelines on case allocation creates a de facto system of allocation based on 'first come, first served', with a relatively strong position for the country where the suspect is first arrested. ${ }^{33}$ It can even be contended that the choice of where a prosecution takes place, is currently largely left to police forces. ${ }^{34}$ It is mostly at the investigative stage that it is explored which country is best placed to prosecute a particular suspect. To what extent forum shopping takes place here is unknown, but diverging expected penalties are likely to be part of the considerations.

\section{Current prospects for a new proposal}

With the entry into force of the Lisbon Treaty, clear priorities were set for the European Union in the field of criminal cooperation, and the topic of transfer of proceedings slipped from the legislative agenda. Ten years have passed since the last work was done on the 2009 proposal, but it seems that recently there has been increased interest in getting it back on the legislative agenda.

The 2019 Romanian presidency of the Council evaluated deficiencies in the legal framework on cooperation in criminal matters. Amongst others, it concluded there was a need to explore the need for a legislative proposal on the transfer of proceedings, preferably in coherence with an assessment of the provisions of Framework Decision 2009/948/JHA on conflicts of jurisdiction. It confirmed the earlier intention that a new instrument should have wider ambitions than the still extant Transfer Convention. ${ }^{35}$ The Presidency suggested starting with a clear assessment of the current caseload of transfers of proceedings and practical application of the available instruments.

At the June 2019 meeting of COPEN, the suggestions of the Romanian presidency were discussed. ${ }^{36}$ The Commission observed that whereas in the field of civil law, jurisdiction matters have been regulated in Europe since 1968, in the field of criminal law such rules are still absent. Otherwise the suggestion to take up the matter again seems to have met with little enthusiasm from Member States delegations. ${ }^{37}$ No new legislative initiatives in the area of judicial cooperation were foreseen in the 2020 draft Strategic Guidelines of the Council. ${ }^{38}$

\footnotetext{
${ }^{32}$ Luchtman [8].

${ }^{33}$ Professor Katalin Ligeti, quoted in Eurojust [6], p. 2.

${ }^{34}$ Schomburg [4] p. 11, who goes so far as to support the idea of a genuine European judicial body to rule on case allocation.

${ }^{35}$ Council: The way forward in the field of mutual recognition in criminal matters - Policy debate. 27.5.2019. 9728/19, p. 17

${ }^{36}$ Council: Summary of discussions COPEN meeting. 4.6.2019. 9968/19, p. 7.

${ }^{37}$ The Presidency reported already in March 2019 little support from the delegations for the idea of putting the topic back on the agenda.

Council: The way forward in the field of mutual recognition in criminal matters - Exchange of views on the basis of a note by the Presidency. 12.3.2019. 6999/19, p. 5.

${ }^{38}$ Council: Strategic guidelines in the field of Justice and Home Affairs. 31.01.2020. 5636/20.
} 
In December 2019, a new European Commission took up its work. The previous strategic programme ended and the Commission is currently orienting itself on the content of a new strategic agenda. In August 2019, Peter Csonka, Head of Unit in charge of criminal justice at the Commission, gave a broad overview of topics that may be in need of further development. ${ }^{39}$ The transfer of proceedings was indeed first on his exploratory list of topics that could be in need of new European Union legislation.

Strong support to do so came from practitioners at the Annual Meeting of European Judicial Network in December 2019. One panel discussion was dedicated to the question of whether a new European Union instrument on the transfer of proceedings was needed. ${ }^{40}$

There was a strong support by the EJN practitioners regarding an EU instrument with clear rules, when to act, what to do, what information to transmit, in what stage the case should be transferred, what are the legal consequences of the transfer of proceedings in the issuing MS (e.g. to dismiss the case, to discontinue the case etc.), what to do with evidence or frozen assets in the issuing country, issues related to the admissibility of evidence etc. It was highlighted that such a new instrument might also encourage the use of Supervision measures as an alternative to provisional detention (FD2009/829/JHA).

During the discussions, the Commission warned that discussions on the 2009 proposal had proven very difficult on the issues of the criteria for and consequences of a transfer. The Commission said it would consider making a new proposal after a thorough assessment and after having consulted with practitioners.

\section{Way forward for a new proposal}

Since 2009, the arguments for adopting a Directive on the transfer of proceedings have only gained in weight. The practical and legal challenges of the current situation are still numerous, which may well explain the strong support amongst practitioners for new legislation. In that light, it appears legitimate to start looking at some areas that need consideration when designing a new Directive on the basis of the work done in 2009.

\subsection{Mutual recognition}

The 2009 proposal was not based on the principle of mutual recognition. The sole ground for refusal permitted the receiving authority to review the grounds for the transfer in its entirety. A new initiative for a Directive in this field should be based on the principle of mutual recognition. Not only does the Treaty on the Functioning of the European Union now set mutual recognition as the guiding principle for new legislation, this would indeed give the instrument a more firm role in cooperation and strengthen foreseeability for all parties involved.

\footnotetext{
${ }^{39}$ Csonka [3], p. 77.

${ }^{40}$ See note 10 .
} 
The principle of mutual recognition itself has undergone development over the last decade. In comparison to the situation in the year 2009, most judicial cooperation within the European Union is now successfully built upon mutual recognition. Moreover, it is no longer 'blind trust' that dominates the cross-border judicial cooperation; the case-law from Luxembourg has now rightly allowed for safeguards for exceptional circumstances. This has all contributed to a high level of trust, which is also needed for cases to be more successfully transferred within the European Union.

Other common features in mutual recognition instruments could also be included in the new Directive. Although seemingly trivial, the introduction of time frames for decisions to be taken has undoubtedly contributed to a more reliable system of international cooperation within the European Union. The 2009 proposal did not yet include any time frame for decision-taking, but this should be included in a renewed proposal. Also, mutual trust presupposes that each Member State has implemented the European Union-required harmonisation of specific crimes. ${ }^{41}$ For those offences subject to European Union approximation, a double criminality test could be abandoned, an approach which has been suggested by Vermeulen, De Bondt, and Ryckman. $^{42}$

\subsection{Involvement of defendants and victims}

It has been rightly pointed out that currently forum choice is often 'an insider's choice'. Both academic writers and practitioners have called upon the European legislator to introduce judicial review of forum choice. In the 2009 proposal only the right to be informed was included. The Meijers Committee commented at the time that it remained unclear for what exact purpose such a right of information was included. ${ }^{43}$ Although the European Union legislator was still reluctant to include a right to judicial review in the European Investigative Order Directive, the far-reaching effects of a transfer of proceeding would be a good reason to consider inclusion of such a right in a Directive on this matter. It seems that such a right should not only pertain to the defendant, but equally to victims in a case. To further ensure that the interests of victims are given due weight in the process of transfer of proceedings, it has been recommended that victim-related criteria be included in the list of situations in which a case may be transferred. ${ }^{44}$

\subsection{Maximum sentence and sentencing practices}

A transfer to another jurisdiction comes possibly with changes to the maximum penalty and to applicable sentencing practices. This can be either advantageous or disadvantageous to the defendant. In the Transfer Convention a lex mitior rule was included, which maximises the maximum sentence to be imposed at the lowest of both jurisdictions involved. The 2009 proposal followed this line.

\footnotetext{
${ }^{41}$ See for a recent overview of achievements in and future development of this field: Csonka and Landwehr [10].

${ }^{42}$ Vermeulen, De Bondt, and Ryckman [9], p. 164.

${ }^{43}$ Meijers Committee [7], p. 2.

${ }^{44}$ Vermeulen, De Bondt, and Ryckman [9], p. 478.
} 
The question seems legitimate of whether the application of lex mitior is always justified. Application of lex mitior implies that automatically more weight is given to the law of the country with the lower maximum sentence. A paramount argument for such a choice is not easily found. It has been pointed out that if both countries hold original jurisdiction over the offence, the suspect may legitimately be expected to foresee that his actions expose himself to a conviction in either country, including the one with the more severe punishment. ${ }^{45}$

Whereas the lex mitior rule determines the applicable maximum penalty to follow, diverging national sentencing practices are a different matter. In most countries, judges enjoy a certain liberty in determining the severity of the penalty to be imposed. With a transfer of proceeding, the transferring authority entrusts serving justice to the receiving state. In line with that trust, it may be argued that the sentence should also reflect the harm done to the legal order of the transferring state. For victims and the general public it might otherwise be hard to accept a transfer to a jurisdiction were sentences in similar cases are much lower.

The idea that foreign sentencing practices are taken into account is exactly what has been done already for decades in relation to the transfer of sentences. In that procedure, a foreign sentence is replaced by a proper national sentence. Here, the severity of the new sentence is not merely determined by national practices, for instance the applicable sentencing guidelines or case law, but rather 'international sensitivities' are also taken into account. Within the European Union, this exequatur procedure has now been abandoned when transferring sentences, as a result of which foreign sentencing practices are already imported. ${ }^{46}$

In a way, one may conclude that the judge in the accepting Member State would hear a transferred case in a capacity as a judge of the European Union legal order, besides its national capacity. It is here that the concept of one European judicial area gets a new dimension. Practically, this could be organised by including reference judgements, the applicable sentencing guidelines or a sentencing advice from the transferring state to the receiving authority.

\subsection{Translations}

The cost of and time needed for translations put a certain brake on the transfer of a proceeding. ${ }^{47}$ The 2009 proposal took as a starting point that a translation of the relevant parts of the file were to be provided by the requesting state. The Explanatory Report to the 2009 proposal observed rather positively that the new instrument would not entail significant additional costs for the Member State.

It seems undeniable that an increase of transfers will bring about a significant rise in translation costs. In fact, it seems essential to detail in a Directive how the rights to information, interpretation and translation will be applied when transferring a case.

\footnotetext{
${ }^{45}$ Ibid, p. 349.

${ }^{46}$ See in particular Article 8 of the Council Framework Decision 2008/909/JHA of 27 November 2008 on the application of the principle of mutual recognition to judgements in criminal matters imposing custodial sentences or measures involving deprivation of liberty for the purpose of their enforcement in the European Union, [2008] OJ L 327/27.
}

${ }^{47}$ Eurojust [6], p. 10. 
If the position of suspects and victims is to be strengthened, then at least a summary of the file should be provided in the language they understand. It seems desirable to clearly establish which authority will be responsible for the selection, costs and organisation of the translation, in each consecutive phase.

Nonetheless, this challenge seems to be primarily connected to the situation in which a transfer is arranged in a late stage of the proceedings. In my own practice, I have prosecuted several drugs suppliers on the basis of foreign files. In my experience, early consultation and a good index of the available evidence helps in the selection of materials to be translated. Consultation between authorities should be part of the answer to this challenge. Moreover, when all parties in a trial agree, there seems little militate against admitting evidence in a foreign language.

\section{Conclusion}

In a genuine shared Area of Freedom, Justice and Security, harmonised arrangements should be in place which allow judicial authorities to transfer cases more easily and in accordance with well-defined harmonised rules, as is the case in every national legal order. 2022 will see the fiftieth anniversary of the Transfer Convention. It would be a significant contribution to European cooperation in criminal matters, if the European Union would agree by then on a Directive on the transfer of proceedings. This Directive would serve two out of the four primary objectives of European Union legislation in criminal matters, as defined in the Lisbon Treaty: it would settle jurisdiction conflicts and facilitates cooperation between judicial authorities. Cases would be more easily brought before the court best placed to decide them, and related cases could be more easily concentrated before a single competent tribunal, in particular in organised crime cases. Although some major points engendering resistance were not resolved in 2009, these discussions may play out differently now that ten years have passed during which the European judicial area has been developing progressively. It is to be hoped that this stumbling block will indeed turn into a cornerstone.

Publisher's Note Springer Nature remains neutral with regard to jurisdictional claims in published maps and institutional affiliations.

Open Access This article is licensed under a Creative Commons Attribution 4.0 International License, which permits use, sharing, adaptation, distribution and reproduction in any medium or format, as long as you give appropriate credit to the original author(s) and the source, provide a link to the Creative Commons licence, and indicate if changes were made. The images or other third party material in this article are included in the article's Creative Commons licence, unless indicated otherwise in a credit line to the material. If material is not included in the article's Creative Commons licence and your intended use is not permitted by statutory regulation or exceeds the permitted use, you will need to obtain permission directly from the copyright holder. To view a copy of this licence, visit http://creativecommons.org/licenses/by/4.0/.

\section{References}

1. Luchtman, M.: Choice of forum and the prosecution of cross-border crime in the European Union. In: Luchtman, M. (ed.) Choice of Forum in Cooperation Against EU Financial Crime - Freedom, Security and Justice and the Protection of Specific EU-Interests. Eleven, The Hague (2013) 
2. Eurojust: Report on Eurojust's casework in the field of prevention and resolution of conflicts of jurisdiction, updated 2018. Available at www.eurojust.europa.eu

3. Csonka, P.: Guest editorial. In: Eucrim, vol. 2, p. 77 (2019)

4. Schomburg, W.: Criminal matters: transnational ne bis in idem in Europe - conflict of jurisdictions transfer of proceedings. ERA Forum 12, 311 (2012)

5. Ludwiczak, M.: Jurisdiction and applicable law in the EU directive on transfer of proceedings in criminal matters. New J. Eur. Crim. Law 3, 343 (2010)

6. Eurojust: Strategic Seminar on Conflicts of Jurisdiction, Transfer of Proceedings and Ne bis in Idem: Successes, shortcoming and Solutions (2015). Available at: www.eurojust.europa.eu

7. Meijers Committee: Observations of the Meijers Committee on the draft framework decision on the prevention and settlement of conflicts of exercise of jurisdiction in criminal proceedings and on the draft framework decision on the transfer of proceedings in criminal matters. CM0905 (2009). Available at: www.commissie-meijers.nl

8. Luchtman, M.: Choice of forum in an area of freedom, security and justice. Utrecht Law Rev. 1, 74 (2011)

9. Vermeulen, G., De Bondt, W., Ryckman, C.: Rethinking International Cooperation in Criminal Matters in the EU. Maklu, Antwerpen (2012)

10. Csonka, P., Landwehr, O.: 10 years after Lisbon - how "lisbonised" is the substantive criminal law in the EU? In: Eucrim, vol. 4, p. 261 (2019) 